\title{
TIME-VARYING HOUSING MARKET FLUCTUATIONS: EVIDENCE FROM THE U.S. HOUSING MARKET
}

\author{
Dicle Ozdemir \\ Faculty of Economics and Administrative Sciences, \\ Mugla Sitki Kocman University, Mugla/Turkey \\ e-mail:dicleozdemir@mu.edu.tr
}

\begin{abstract}
The objective of this paper is to investigate how the housing market and credit market factors contribute to US business and interest rate cycles in a time-varying transition probability modeling framework. The Markov switching results appear to exhibit periods of low-growth regime and highgrowth regime for both house and credit markets. The study also shows that the transition probabilities reflecting the regime switching behavior of business and interest rate cycles vary over time as functions of the house and credit market. We find that both the housing market and credit market contribute to whether the economy remains in a high-growth regime or moves into lowgrowth regime, and whether the interest rates remain in a low or high-growth regime. The results show that the housing market plays a leading role in affecting the time-varying probabilities between regimes for the business and interest rate cycles.
\end{abstract}

Key words: business cycles, housing market, Markov Switching, interest rate.

JEL Classification: C22, E32, E44.

Citation: Ozdemir, D. (2020). Time-varying housing market fluctuations: evidence from the U.S. housing market. Real Estate Management and Valuation, 28(2), 89-99.

DOI: https://doi.org/10.1515/remav-2020-0018

\section{Introduction}

Housing market fluctuations have a strong positive relationship with business cycles. Since housing market credit conditions may significantly affect the collateral value of houses, the fluctuations in house prices play a significant role in determining household borrowing conditions, and thereby the growth cycles of an economy. Semmler and Bernard (2012) point out that the 2008 financial crisis was in fact a housing market crisis resulting from some macroeconomic changes, such as financial market liberalization; low interest rates and easy credit conditions with leveraged loans stimulated financial derivatives, including varieties of new financial innovations. The authors argue that if borrowing is not fully covered by the collateral value of assets, leveraging may trigger asset price boom/busts, and hence, financial disturbances. At this point, we should pay more attention to the linkages between leverage and expectations. In a financial market, employed by sophisticated derivative financial instruments without real reserve restrictions, leverage and expectations combine to form a selffulfilling process; this implies higher asset prices, and thus collateral values, inducing both borrowers and lenders to feel more optimistic, and hence, leading to decreased minimum leverage ratio requirements. Growth in leveraged loans will result in higher asset prices, which will be driven up even further, as well as reinforcing positivity and optimism, thereby revealing higher leverage levels, which may entail significant financial risks (Howitt, 2001).

Using short-term nominal interest rates as the main instrument of monetary policy is another key issue in mainstream macroeconomic models. Much of the pioneering academic and policy works have 
discussed the role of interest rates throughout the boom-bust cycles of an economy. Since monetary shocks can affect an economy via interest rates, this is an important channel of business cycles. Interest rates, as a function of exogenous forces, play a key role in the mainstream theories of business cycles. However, the link between interest rates and house price bubbles is intuitive; expansionary monetary policies cause higher bond prices and lower interest rates and, consequently, fluctuations in asset price boom-bust cycles. For instance, lower interest rates stimulate consumption of durable goods, encourage additional investment spending and finally, increase the demand for credit and assets. Particularly, as Kim and Coulson (1999) stated, lower interest rates can significantly affect the cost of financing and mortgage rates, which may eventually lead to a rise in housing prices and motivate the commencement of new housing. In short, interest rates play a crucial role in both business cycles and housing market boom and bust phases. Consequently, low interest rates will almost certainly drive up property prices, and vice versa if high interest rates prevail in the money market. Conversely, if the economy is overheated when inflation increases, central banks raise interest rates, home sales slump, and finally, economic activity begins to slow. In short, interest rates play a crucial role in both business cycles and housing market boom and bust phases. In this sense, we examine the role and the cyclical behavior of interest rates and economic growth based on an empirical analysis of changes in regimes in the U.S. housing market in a credit-driven perspective.

The methodology of this paper comes from the papers of Hamilton $(1989)$, Chauvet $(1998,1999)$ and Sun (2012). The aim is to investigate whether the housing market and the credit market factors contribute to US business and interest rate cycles. The model used is a common factor model suggested by Stock and Watson $(1991,1993)$, Chauvet $(1998,1999)$, which is built from a dynamic factor based on the extraction of principal components from a large number of real estate market indicators, Hamilton's (1989) regime switching model, which characterized by the time series behaviors in different regimes, and finally Filardo's (1994) time-varying transition probabilities for Markov Regime switching model, which let transition probabilities vary over time as the specific transformations of lagged observations.

Chauvet $(1998,1999)$ built a dynamic factor model of the Stock and Watson $(1991,1993)$ model to extract the common movement underlying a set of variables that lead to inflation and extends Hamilton's approach using a multivariate Markov switching dynamic factor model to capture business cycle and stock market factor movements. In this study, we derived common factors for the two parts of the US housing sector using the same data and method as presented by Sun (2012) and Chauvet $(1998,1999)$. In this sense, two different approaches are considered to examine the housingbusiness cycle and housing-interest rate cycle relationships. First, a Univariate Markov regime switching model is used to analyze the regime switching behavior of each common factor. Then, to examine whether the housing or credit market factors play a leading role in business or interest rate cycles and to determine whether the transition probabilities can vary with the business and interest rate cycles, we estimate the Markov-Switching two-regime autoregressive model, using variabledependent transition probabilities for the case of U.S. Housing market, Filardo's (1994) time-varying transition probabilities for Markov Regime switching model is specified for each common factor. Both the housing market common factor and credit market common factors are expected to influence the fluctuations of business and interest rate cycles. Thus, the main contribution of this study is that it examines whether the effects of changes in house and credit market common factors on business and interest rate cycles differ in times of high growth and low growth regimes when allowing the transition probabilities driven by the lagged common factors to vary over time.

The rest of this paper is organized as follows: Section 2 presents a literature review. Section 3 provides a discussion of the empirical methodology and data. Section 4 presents the empirical results. Section 5 is the conclusion.

\section{Literature review}

Many studies focus on modeling the linear and nonlinear relationships between the housing market cycles and business cycles. Jin and Zeng (2003) build a three-sector model driven by monetary and productivity shocks to investigate the relationship between house prices, residential investment and business cycle for the U.S. data. They show a procyclical behavior of house prices and business cycles as well as residential investments. Based on a decomposition of quarterly state level house prices between 1986 and 2005 using a dynamic factor model, Del Negro and Otrok (2005) attributed a limited role to the long term interest rates in explaining the house price fluctuations across U.S. states. Ceron 
and Suarez (2006) estimated house price volatilities for 14 countries using the Markov regime switching model and found that the movements of house prices can be explained by the GDP growth and interest rates, and additionally, that low and high regimes of the house price volatilities were able to predict house price movements. Moreover, their results demonstrated that the duration of regimes of house price volatilities lasts about 6 years on average. Cunningham and Kolet (2007) estimated the durations and correlations of housing market cycles using panel data the aggregate and city level for the U.S. and Canada. The authors found that there is a high correlation in house price cycles among the U.S. and Canada cities. Beidos-Strom et al. (2009) investigate some developments in housing finance and their linkage to the macroeconomic conditions using a synthetic index of the mortgage market which consists of six indicators derived from the 16 emerging economies. They find that mortgage markets lead to lower consumer spending volatilities. Ghent and Owyang (2010) examine the link between residential investment and business cycles using housing permits and employment data for the U.S. between 1984 and 2008. Although they find a close link between national housing permits and the city's employment, they found no direct evidence to suggest that a city's permits or prices influence its business cycle. They conclude that house price is not a good leading indicator for forecasting the cyclical turning points, which is seemingly contradictory to previous studies. Alvarez et al. (2010) examine the link between housing cycles and business cycles and investigated synchronizations across the four largest euro area countries. They find that, while idiosyncratic factors play a major role in housing cycles, the growth cycles are highly synchronized across the euro area countries. On the other hand, Ferrara and Koopman (2010) find no evidence of comovements of the housing cycles across the Euro area in spite of a strong common cycle between French and Spanish housing cycles. Christidou and Konstantinou (2011) performed a study by assessing a VAR model for the 48 U.S. states between 1988 and 2009 to examine the effect of monetary policy shocks on real house prices and housing investments and investigate the macroeconomic effects of wealth shocks in housing market. The results suggest that that the transmission of monetary policy is heterogeneous among the U.S. states.

In addition to the above, a large number of existing studies in the literature have examined the link between interest rate and house price cycles. Himmelberg et al. (2005) compared house price dynamics and changes in fundamental determinant factors for the housing market using a user-cost formulation for 46 metropolitan areas in the U.S. between 1979 and 2004. The study suggests that that house price changes are sensitive to changes in interest rates, especially in areas where prices grow relatively faster. Moreover, they show a self-fulfilling mechanism between the sensitivity of house prices and house price expectations. Mc Carthy and Peach (2004) examined house price and interest rate dynamics between 1999 and 2004 for U.S. states. Their findings indicate that interest rate is an appropriate measure of affordability and earnings of homeowners, and moreover, fundamentals of the economy can explain house price patterns. However, they found no evidence of bubbles except in a few states. Martinez Pages and Maza (2003) is another study examining the evolution of house prices as a function of gross disposable income and interest rate using an error correction model between 1978 and 2002 for Spain. The result suggests that both income and interest rate are explanatory factors for house price patterns. Englund and Ioannides (1997) estimated the effects of GDP growth rate and interest rate on house price cycles and reported a high significant autocorrelation for those countries using a panel of 15 OECD countries between 1970 and 1993. Furthermore, their findings revealed a strong linkage among house price movements, real interest rate changes and GDP growth rate. Mc Donald and Stokes (2011) studied the effects of the federal funds rate on the U.S. house price index using VAR-based Granger causality tests, for the period between 1987 and 2010. The authors' finding is that there is a unidirectional causality running from the federal funds rate to the house price index with an inverse relationship between the house price index and the federal funds rate. A similar study was applied by Jarocinski and Smets (2008) using a VAR model with nine endogenous variables to examine whether the changes in housing prices are caused by the federal funds rate using data from 1987 to 2007 . They pointed out that the impulse response of house prices to the federal funds rate is statistically significant and negative.

Empirical evidence on the leading role of house price dynamics with respect to the business cycles in the UK, US and Spain was also developed by Dufrenot and Malik (2012) and tested with a timevarying transition probability Markov switching model. The authors conclude that business cycle turning points may be attributed to asymmetric house price fluctuations, which may lead to recessions 
in the following period. Finally, there is a substantial body of work that investigates housing market fluctuations under various macroeconomic and financial factors. Bordo and Landon-Lane (2014) claim that booms in housing and commodity markets may have been preceded by expansionary monetary policies. S'a et al. (2014) provides evidence on the role of shocks to capital inflows in leading to the occurrence of housing fluctuations. Kim and Chung (2016) claim that changes in house prices significantly affect the transition of the US economy between the recession-expansion phases. More recent empirical studies on housing market dynamics include investigating linkage and transmission channels within credit market conditions (Agnello, et al., 2018), financial markets (Wang \& Zong, 2019), monetary policy shocks (Chatziantoniou, et al., 2017), households' expectations (Huang, 2019), securitization, mortgage sector liberalization and government involvement (Angello, et al., 2019), population growth and air quality (Funke, et al., 2019) and cost of housing burden (Tsai, 2019).

\section{Data and Methods}

Two different common factors are derived from the US house and credit markets' series separately. Following the same approach and procedure as Sun (2012), the model is based on the U.S. housing market common factors derived from two sets of quarterly data. The dynamic factor model, introduced by Stock and Watson (1991, 1993), extracts a common factor from four coincident macroeconomic variables. This unobservable variable represents the general "state of the economy." Both series cover the periods from 1974Q1 to 2013Q2. Each factor, representing the house and credit market, is extracted from four variables. A dynamic factor model with the Kalman filter is used to construct a common factor of the housing market and house credit market separately. The housing market common factor is constructed based on the following series: new private housing units authorized by building permits (PHU), new single family houses sold (SFH), median sales price of new homes sold (MSP) and new privately owned single housing unit starts (NPH). Following the same procedure above, four series are selected to represent the credit market: The conventional (30-year fixed) mortgage rate (FMR), real household credit market debt outstanding (CDO), real households and nonprofit organizations home mortgages (HMD) and the house rental vacancy rate (HRV). The MSP, CDO and HMD are deflated by 2005 prices with the Consumer Price Index (CPI for All Urban Consumers: All Items Less Food \& Energy), obtained from the U.S. Department of Labor: Bureau of Labor Statistics. All variables, except the CDO and MSP series which are in percentage points, are used in natural logarithmic form. The extracted dynamic factors are compared to cyclical fluctuations in real Gross Domestic Product (GDP) (billions of chained 2009 Dollars), seasonally adjusted, which is obtained from Federal Reserve Economic Data (FRED) and used in one hundred times the first difference of the logarithm. The interest rate is represented by the effective federal funds rate which is derived from the Board of Governors of the Federal Reserve System. Figure 1a and $1 \mathrm{~b}$ plots the housing market and credit market common factor components, respectively.

Most of the time, series models which have attempted to examine the behavior of real estate markets are limited by their linear form, which are incompatible with the asymmetric behaviors. To highlight this limitation, we apply the Markov switching model of Hamilton $(1989,1994)$, also known as the regime switching model.

To investigate a causal link from the housing market and credit market to business and interest rate cycles, we employ Hamilton's (1989) state dependent Markov-switching model. The AR(4) process is chosen primarily due to the quarterly data modeled in this study, as well as the fact that popular applications in business cycle research are built with the AR(4) process in two different regimes (see e.g. Hamilton, 1989; Durland \& McCurdy, 1994; Goodwin, 1993; Moolman, 2004). A twostate Markov Switching autoregressive model (MS-AR) can be described as follows:

$$
\begin{aligned}
& \left(\Delta y_{t}-\mu_{S_{t}}\right)=\alpha_{1}\left(\Delta y_{t-1}-\mu_{S_{t-1}}\right)+\alpha_{2}\left(\Delta y_{t-2}-\mu_{S_{t-2}}\right)+\alpha_{3}\left(\Delta y_{t-3}-\mu_{S_{t-3}}\right)+\alpha_{4}\left(\Delta y_{t-4}-\mu_{S_{t-4}}\right)+\varepsilon_{t} \\
& e_{t} \square \text { i.i.d.N }\left(0, \sigma^{2}\right) \\
& \mu_{S_{t}}=\mu_{1}\left(1-S_{t}\right)+\mu_{2} S_{t}
\end{aligned}
$$




\section{$S$ sciendo}

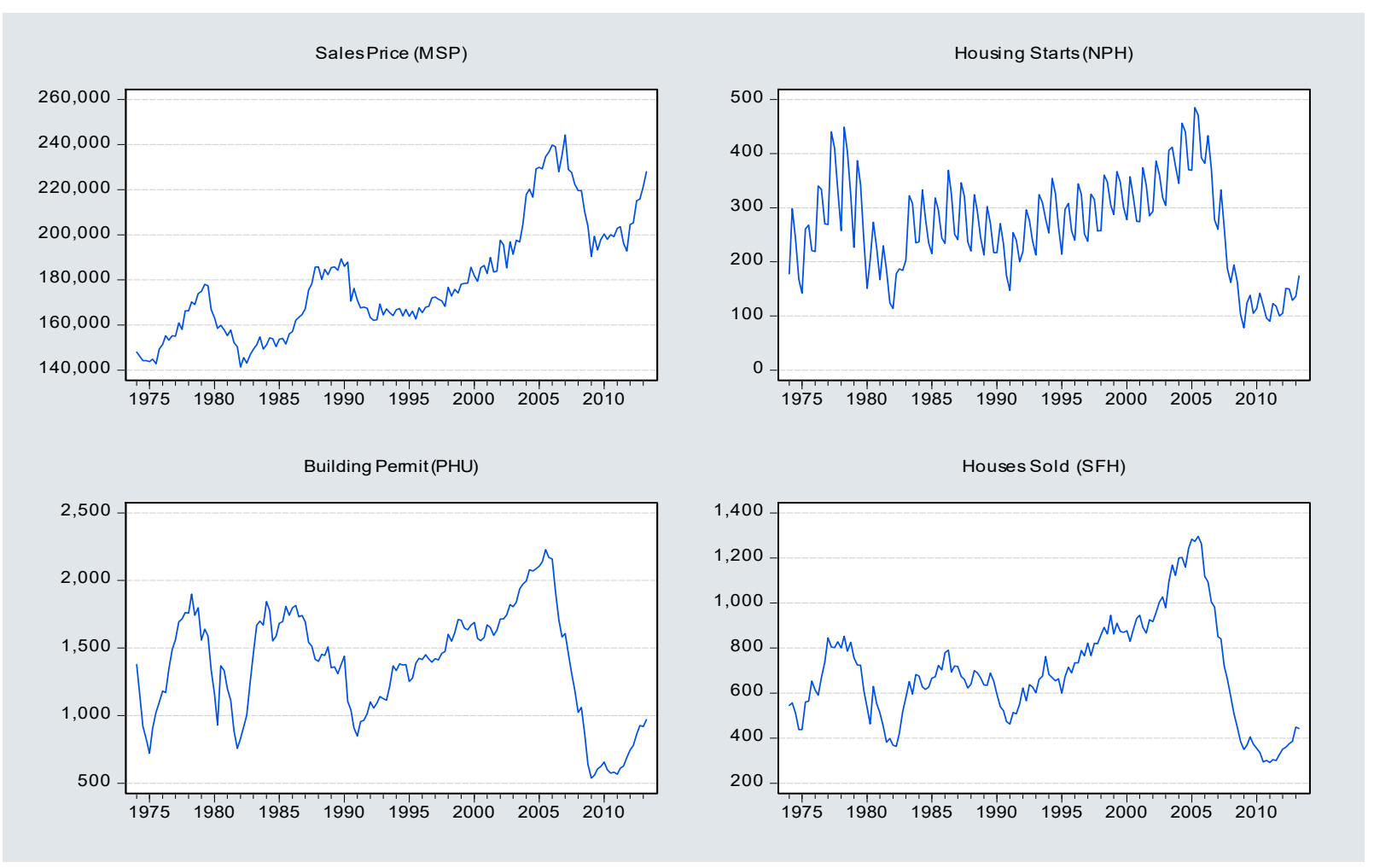

Fig. 1a. Housing Market Common Factor Components. Source: Federal Reserve Economic Data (FRED).

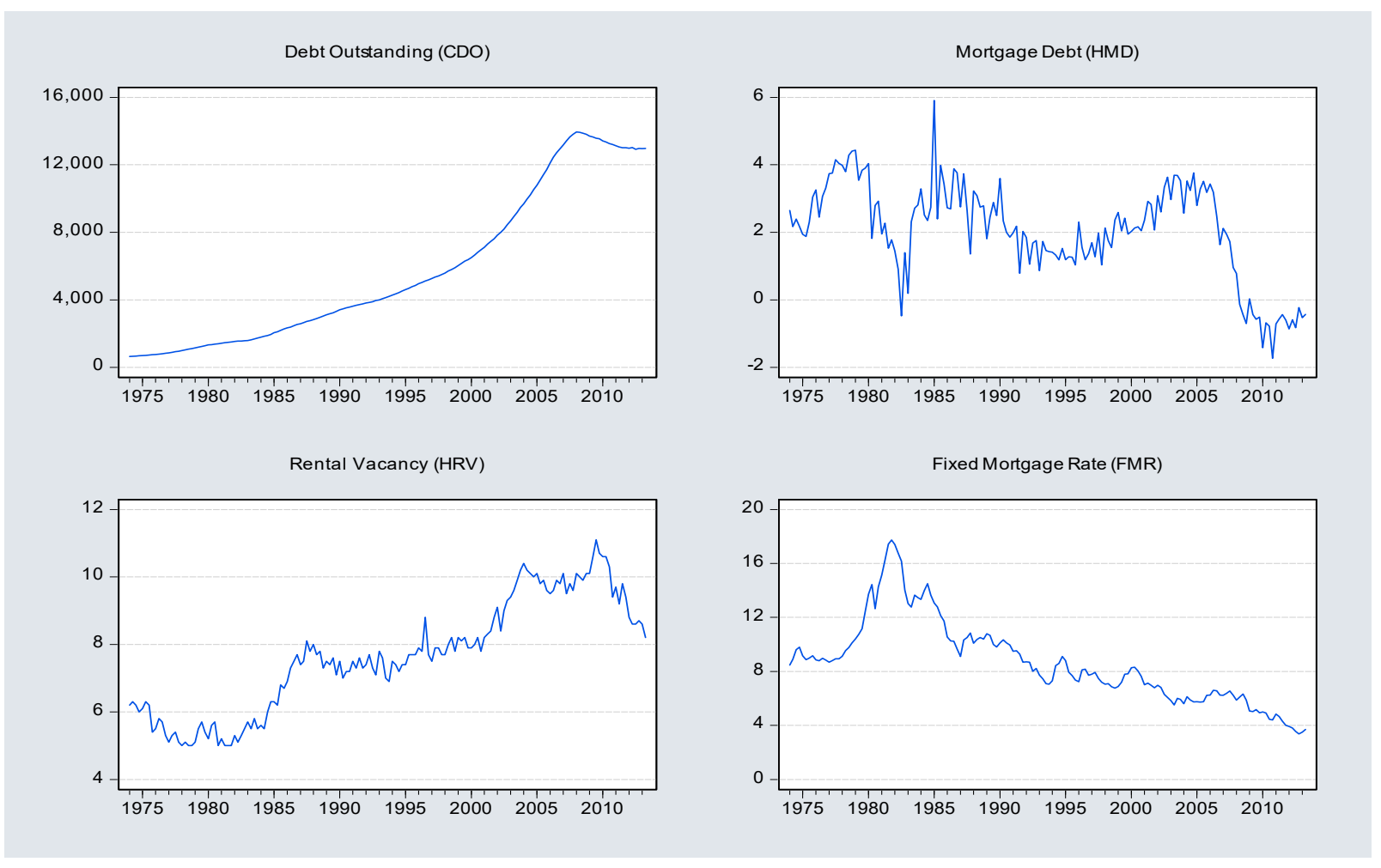

Fig. 1b. Credit Market Common Factor Components. Source: Federal Reserve Economic Data (FRED).

where $\Delta y_{t}$ represents the dependent variable switching between the regimes; that is, based on the employed model, it will be the first difference of log of real GDP as a proxy for business cycles or the first difference of federal funds rate as a proxy for interest rate cycles or the first difference of the 
house and credit market common factors. $\mu_{s t}$ is the mean of the variable growth when the variable is at regime $S_{t}$. Our model is a two-regime Markov switching autoregressive model, where the term $S_{t}$ is the latent regime variable which could take the value of 1 or 2 depending on the state or regime of the variable. $S_{\mathrm{t}}=1$ or 2 , which switches between the low and high growth regimes for the interest rate, or between the low growth rate and the high growth rate regimes for the GDP growth, housing market and credit market. The unobservable state variable is governed by a first order Markov chain with a constant transition probability matrix $(\mathrm{P})$ :

$$
P=\left[\begin{array}{ll}
\operatorname{Pr}\left(S_{t}=1 \mid S_{t-1}=1\right. & \operatorname{Pr}\left(S_{t}=2 \mid S_{t-1}=1\right. \\
\operatorname{Pr}\left(S_{t}=1 \mid S_{t-1}=2\right. & \operatorname{Pr}\left(S_{t}=2 \mid S_{t-1}=2\right.
\end{array}\right]=\left[\begin{array}{ll}
p_{11} & p_{12} \\
p_{21} & p_{22}
\end{array}\right]
$$

where $\mathrm{p}_{\mathrm{ij}}$ are the transition probabilities from state $i$ to regime $j$.

We also employ the Time-Varying Transition Probabilities (TVTP) model, as Filardo (1994) proposed, to capture the transition probabilities between the regimes that might give information about the economic environment. Since variations in the transition probabilities lead to variations in the expected durations, this methodology allows us to detect how transition probabilities change throughout the business cycles. The advantage of TVTP modeling is that it allows transition probabilities to be time-varying. (Filardo, 1994; Filardo \& Gordon, 1998).

To employ the model, first of all, a connection should be created between the transition probabilities and the probability inferred on the state of the economy (Filardo, 1994). The probability inferred on the state of the economy in time $t$ can be calculated by integrating the effect of the past values of $y_{t}$ and the probability density function. Once the ML estimates are obtained, we are able to calculate the probability of $S_{t}=1$ or $S_{t}=2$ for each time period. The transition probabilities are modeled as follows:

$$
p\left(z_{t}\right)=\frac{\exp \left(\theta_{p 1}+\theta_{p 2} z_{t-1}\right)}{1+\exp \left(\theta_{p 1}+\theta_{p 2} z_{t-1}\right)}
$$

and,

$$
\mathrm{q}\left(z_{t}\right)=\frac{\exp \left(\theta_{q 1}+\theta_{q 2} z_{t-1}\right)}{1+\exp \left(\theta_{q 1}+\theta_{q 2} z_{t-1}\right)}
$$

where $z_{t-1}$ is the lagged common factors, $\theta_{1}$ and $\theta_{2}$ are the coefficients that determine the effect of the $z_{t-1}$ on the time variation of $\mathrm{p}$ and $\mathrm{q}$ respectively. By employing the TVTP model, we investigate whether the relevant common factor $\left(Z_{t}\right)$ plays a dominant role in influencing the regime switching process of GDP and interest rate. That is to say, we consider whether the coefficients of the market common factor $\theta_{p j}$ and $\theta_{q j}$ are statistically significant to capture the regime changes during business and interest rate cycles (Compton \& Silva, 2005).

\section{Empirical results}

\subsection{Univariate Markov Switching Model}

Table 1 presents the Markov switching parameters and the maximum likelihood estimates for the housing market common factor from 1974:Q2 to 2013:Q2. The low growth (negative mean) of the housing market factor is at state 1, which is associated with the NBER recessions; on the other hand, the high growth (positive mean) of the housing market factor is represented by regime 2, which is associated with the economic expansion periods. Autoregressive coefficients and post-estimation tests are not reported, but available from the author upon request. The mean of regime 1 is -0.664 and the mean of regime 2 is 0.123 . The log likelihood for this model is -62.980 . The probability of the high growth housing market occurring is 0.957 compared to the probability of 0.660 for the low growth housing market regime. For the credit market, Table 1 also details the respective Markov switching parameters and shows the maximum likelihood estimates for the housing market common factor from 1974:Q2 to 2013:Q3. The log likelihood for this model is -153.224 . The low growth regime of the credit 
market factor is at regime 2, which is associated with the NBER recessions; on the other hand, the high growth regime of the credit market factor is at regime 1 . The mean of regime 2 is -2.033 and the mean of regime 1 is 2.979 . The probability of the high growth in credit market occurring is 0.951 , compared to the probability of 0.884 for the low growth credit market regime. In the model, "recession" refers to business cycle contraction with low mean growth regime. The NBER declares a recession as "a period of falling economic activity spread across the economy, lasting more than a few months." In this study, the Markov-switching regimes are closely related to NBER-dated recessions and expansions.

Table 1

Parameter Estimates of the Respective Market Segment Markov Switching Model

\begin{tabular}{ccc}
\hline & Housing Market & Credit Market \\
\hline Parameters & Estimate & Estimate \\
\hline$\mu_{1}$ & $-0.664(0.550)$ & $2.979(0.589)$ \\
\hline$\mu_{2}$ & $0.123(0.476)$ & $-2.033(0.527)$ \\
\hline $\mathrm{p}_{11}$ & 0.660 & 0.951 \\
\hline $\mathrm{p}_{22}$ & 0.957 & 0.884 \\
\hline $\log \mathrm{L}$ & -62.980 & -153.224 \\
\hline
\end{tabular}

The numbers in parentheses are asymptotic standard errors

* indicates that the p-value is not significant at $5 \%$ level

Source: own study.

Figure 2 presents the smoothed probabilities for the housing market. The housing market common factor switches to a low growth regime in 1974, 1980, 1981-82, 1990-91 and 2007-2009, coinciding with the recessions throughout the period. The housing market factor fails to switch in the neighborhood of the 2001 recession. Indeed, the smoothed probabilities show that the financial crisis of 2001 and dotcom bubble had little effect on the housing market sector. The results appear to show that the housing sector plays an important role in determining business cycle fluctuations; furthermore, any change from a high growth regime to a low growth regime of the housing sector points to recessions for the periods 1974, 1980, 1981-82, 1990-91 and 2007-09.

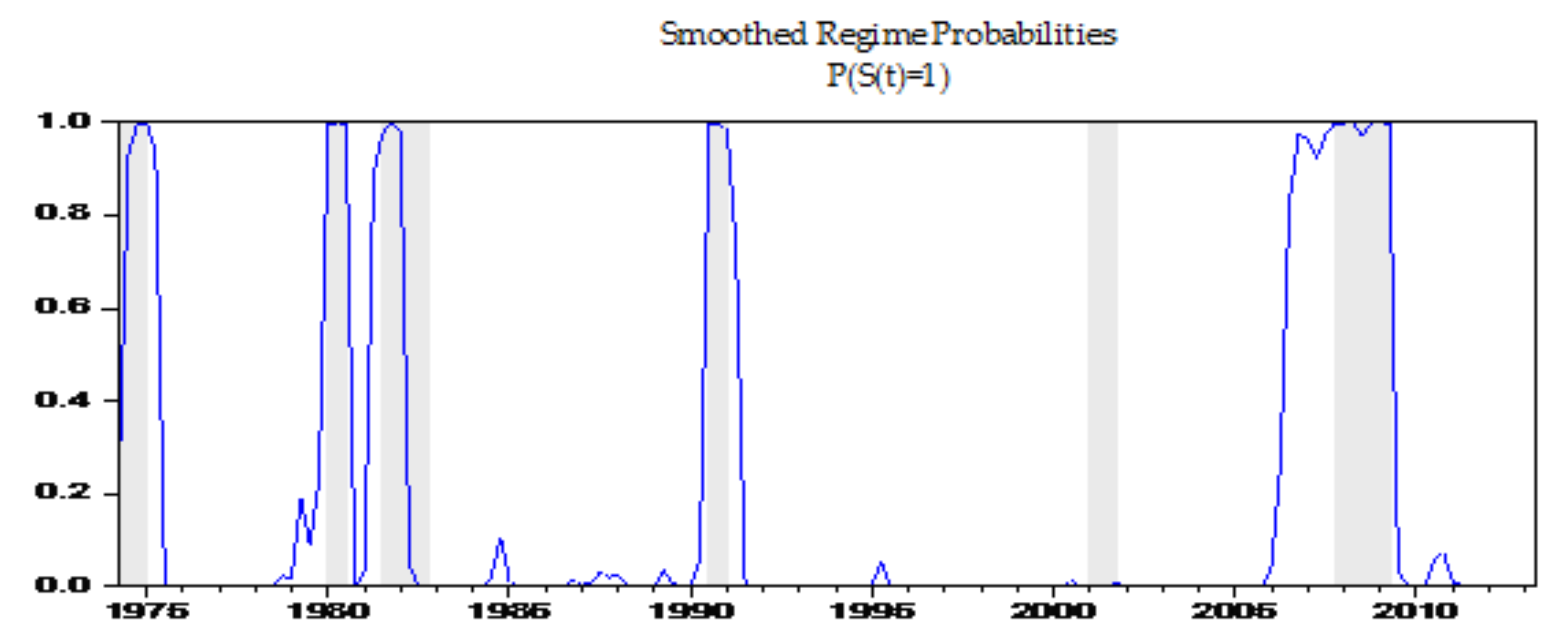

Fig. 2. Smoothed Probabilities for Low Growth Regime (Housing Market Common Factor). Source: own study

Figure 3 displays the smoothed probabilities of the low growth regime for the credit market common factors, respectively. The credit market factor switches to a low growth regime over the 1975, 1980, 1981-82 and 2008-09 recessions. The credit market factor presents weak spikes a quarter after the 1990-91 recession begins and during the 2001 recession. 


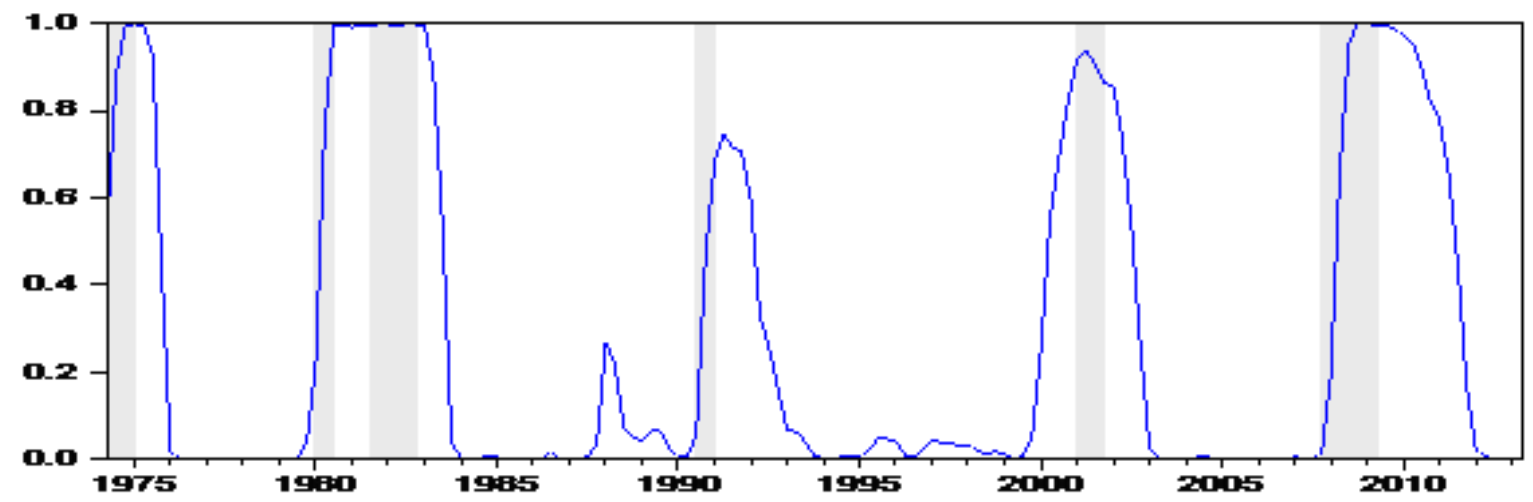

Fig. 3. Smoothed Probabilities for Low Growth Regime (Credit Market Common Factor). Source: own study.

\subsection{Time-Varying Transition Probabilities Model}

In this section, we investigate to what extent a set of leading variables, $Z_{t}$, the lag of the housing market and house credit market common factors, affect the business and interest rate cycles. A possible housing market-business cycle and housing market-interest rate cycle dynamics that capture Filardo's time varying transition probability can be seen in Table 2 , which details the TVTP estimation results for both common factors as shown by the parameters $\theta_{\mathrm{p} 1}$ and $\theta_{\mathrm{q} 1}$. For the housing market common factor as a leading variable for the real GDP cycles, $\theta_{\mathrm{p} 1}$ is positive and statistically significant, while $\theta_{\mathrm{q} 1}$ is negative and not statistically significant. That is, an increase in the housing market common factor leads to a higher probability of remaining in an expansionary regime associated with higher interest rates. This shows that the housing market common factor provides strong predictive power forthe GDP growth regime switching and supports the statement that the housing market plays a crucial role in the occurring GDP fluctuations. When considering the housing market factor as a leading indicator for the interest rate regime changes, $\theta_{\mathrm{q} 1}$ is statistically significant and negative, and $\theta_{\mathrm{p} 1}$ is statistically significant and positive. That is to say, higher growth in the housing market factor is associated with higher probabilities of being in the high interest rate regime.

Table 2

Time Varying Transition Probability Coefficients

\begin{tabular}{lcccc}
\hline & \multicolumn{2}{c}{ Real GDP Cycles } & \multicolumn{2}{c}{ Interest Rate Cycles } \\
\hline & Housing Market & Credit Market & Housing Market & Credit Market \\
\hline Parameters & Estimate & Estimate & Estimate & Estimate \\
\hline$\mu_{1}$ & $0.824(0.055)$ & $0.815(0.062)$ & $2.120(0.232)$ & $2.081(0.234)$ \\
\hline$\mu_{2}$ & $-1.0520 .214)$ & $-1.014(0.349)$ & $-0.730(0.110)$ & $-0.748(0.113)$ \\
\hline$\theta_{\mathrm{p} 1}$ & $5.020(1.178)$ & $3.737(0.725)$ & $2.205(0.174)$ & $1.914(0.557)$ \\
\hline$\theta_{\mathrm{q} 1}$ & $-5.330(1.945)^{*}$ & $-4.956(3.064)^{*}$ & $-2.895(0.469)$ & $-2.820(0.450)$ \\
\hline Time-varying transition probabilities & & & \\
\hline $\mathrm{p}_{11}$ & 0.939 & 0.974 & 0.878 & 0.853 \\
\hline $\mathrm{p}_{22}$ & 0.945 & 0.948 & 0.941 & 0.943 \\
\hline Log L & -163.761 & -169.976 & -249.210 & -256.391 \\
\hline
\end{tabular}

The numbers in parentheses are asymptotic standard errors

* indicates that the p-value is not significant at $5 \%$ level

\section{Source: own study.}

When considering credit market as the leading variable for real GDP regime changes, $\theta_{\mathrm{q} 1}$ is not statistically significant, while $\theta_{\mathrm{p} 1}$ is positive and statistically significant, which shows that being in the high credit growth regime leads to higher probabilities of remaining in the GDP expansionary regime. That is, the economy continues to benefit from house credit flows, but credit crunches would harm the wider economy. This evidence also implies that the credit common factor is important in determining 
the predictive power of business cycle regime switching. This is in line with the argument that credit expansion is one of the main factors in driving business cycles movements. For the interest rate regime changes, the time-varying coefficients indicate $\theta_{\mathrm{p} 1}$ is positive and significant while $\theta_{\mathrm{q} 1}$ is negative and statistically significant. In other words, an increase in the credit market common factor measure increases the probability of remaining in the high-growth interest rate regime in the next period. This might be due to the fact that the main determinant of interest rates in the post-war years is the U.S. Federal Reserve's easy monetary policy, and hence, the expansion of credits and mortgages to highrisk borrowers; this would mean that the federal funds rate is determined by liquidity preference conjointly with a supply of money from the banking system, and even if it is pegged by the Federal Reserve to keep the level of economic activity, it in turn reacts back on the demand for money since pegged rates tend to move procyclically (Nell, 1998).

Our results show clear evidence that the house and credit market jointly play a crucial role in determining whether the economy remains in high growth and interest rate regimes. The states of the housing and credit markets have significant explanatory power in explaining regime fluctuations. Markov switching results display a close relationship between the housing market common factor and business cycles. The credit market common factor also supports a similar statement as credit market regime switching bears a crucial role in determining business cycles. In other words, the TVTP model shows evidence that both the housing market common factor and credit market common factor play an important role in changes between the low and high growth regime switching behaviors of GDP and interest cycles. Our empirical results are consistent with those reported in the studies by Dufrenot and Malik (2012), which assessed that the deflation of the housing boom might have led to a severe slump in the following period, and in accordance with findings reported by Kim and Chung (2016), which revealed that changes in house prices can contribute to the switching of the US economy between different regimes.

\section{Discussion and conclusions}

The purpose of this study was to examine the link between housing market common factors, business and interest rate business cycles using Time-varying Transition Probabilities model. The results here show that the regime behaviors of the housing and credit markets have significant explanatory power on business and interest rate fluctuations. First of all, the results show the existence of two regimes, as low and high growth regimes. Secondly, these findings provide strong support for the view that both the housing market and credit market common factors play a leading role for both business and interest rate cycles. These results support the view that the incorporation of regime shifts in the housing market and credit market may contribute to improving our understanding of boom-bust cycles of the general economy.

These findings suggest that the incorporation of regime shifts in the house and credit market may help improve our understanding of the boom-bust periods of general economy. It can be noted that, the relative movements of real GDP growth and the real interest rate also have important implications. In a complex global financial system associated with high degrees of leveraged credits, a large divergence might emerge between real estates and their financial counterparts since, for instance, if the real interest rate is higher than the income growth rate, then house credits will be expensive and real estate investments will look less attractive, which eventually leads to lower income growth. However, a cyclical pattern of interaction between the real and financial sides of the real estate market will eventually begin to emerge. The consequences of such interactions will be observable more strictly during crisis periods.

This paper applies the Markov switching autoregressive model to U.S. data for interpreting housing sector cycles, interest rate cycles and business cycles, respectively. For future research, information regarding switching probabilities within a Bayesian framework using Markov Chain Monte Carlo (MCMC) techniques under a bivariate model, where both state-level data and national data are stacked in the vector of dependent variables would be more suitable for achieving more efficient estimation. Moreover, if the optimal number of regimes and regime-specific parameters are determined under a Bayesian framework, then the Markov regime switching model provides reliable prediction of macroeconomic cycles and their relationship with real estate valuation from historical data by Bayesian inference. 


\section{References}

Álvarez, L. J., Bulligan, G., Cabrero, A., Ferrara, L., \& Stahl, H. (2010). Housing Cycles in the Major Euro Area Countries. In O. de Bandt, T. Knetsch, J. Peñalosa, \& F. Zollino (Eds.), Housing Markets in Europe (pp. 85-103). Springer. https:// doi.org/10.1007/978-3-642-15340-2_5

Agnello, L., Castro, V., \& Sousa, R. M. (2018). Economic activity, credit market conditions and the housing market. Macroeconomic Dynamics, 22(7), 1769-1789. https://doi.org/10.1017/S1365100516000869

Agnello, L., Castro, V., \& Sousa, R. M. (2019). The Housing Cycle: What Role for Mortgage Market Development and Housing Finance? The Journal of Real Estate Finance and Economics. Advance online publication. https:// doi.org/10.1007/s11146-019-09705-z

Beidas-Strom, S., Lian, W., \& Maseeh, A. (2009). The Housing Cycle in Emerging Middle East Economies and its Macroeconomic Policy Implications. International Monetary Fund Working Paper, WP09/288.

Bordo, M. D., \& Landon-Lane, J. (2014). Does expansionary monetary policy cause asset price booms:Some historical and empirical evidence. In S. Bauducco, L. Christiano, \& C. Raddatz (Eds.), Macroe-conomic and Financial Stability: Challenges for Monetary Policy (1st ed., Vol. 19). Central Bank of Chile.

Ceron, J. A., \& Suarez, J. (2006). Hot and cold housing markets: International evidence. CEPR Discussion Paper, 5411.

Chatziantoniou, I., Filis, G., \& Floros, C. (2017). Asset prices regime-switching and the role of inflation targeting monetary policy. Global Finance Journal, 32(C), 97-112. https://doi.org/10.1016/i.gfi.2015.12.002

Chauvet, M. (1998). An Econometric Characterization of Business Cycle Dynamics with Factor Structure and Regime Switching. International Economic Review, 39(4), Symposium on Forecasting and Empirical Methods in Macroeconomics and Finance, 969-996. https://doi.org/10.2307/2527348

Chauvet, M. (1999). Stock Market Fluctuations and the Business Cycle. Journal of Economic and Social Measurement, 25(3-4), 235-257. https:// doi.org/10.3233/JEM-1999-0166

Christidou, M., \& Konstantinou, P. (2011). Housing Market and the Transmission of Monetary Policy: Evidence from U.S. States. Discussion Paper Series, 14, Department of Economics, University of Macedonia.

Compton, R. A., \& Silva, J. R. (2005). Finance and the Business Cycle: a Kalman Filter Approach with Markov Switching. Working Papers Series, 97, Central Bank of Brazil, Research Department.

Cunningham, R., \& Kolet, I. (2007). Housing Market Cycles and Duration Dependence in the United States and Canada. Bank of Canada Working Paper, no. 2.

Del Negro, M., \& Otrok, C. (2005). Monetary policy and the house price boom across US states. Federal Reserve Bank of Atlanta working paper, 24.

Dufrénot, G., \& Malik, S. (2012). The changing role of house price dynamics over the business cycle. Economic Modelling, 29(5), 1960-1967. https://doi.org/10.1016/j.econmod.2012.05.029

Durland, M., \& McCurdy, T. H. (1994). Duration-Dependent Transitions in a Markov Model U.S. GNP Growth. Journal of Business \& Economic Statistics, 12(3), 279-288.

Englund, P., \& Ioannides, Y. M. (1997). House Price Dynamics: An International Empirical Perspective. Journal of Housing Economics, 6, 119-136. https://doi.org/10.1006/jhec.1997.0210

Ferrara, L., \& Koopman, S. J. (2010). Common Business and Housing Market Cycles in the Euro Area from a Multivariate Decomposition. In O. de Bandt, T. Knetsch, J. Peñalosa, \& F. Zollino (Eds.), Housing Markets in Europe (pp. 105-128). Springer. https:// doi.org/10.1007/978-3-642-15340-2_6

Filardo, A. J. (1994). Business Cycle Phases and Their Transitional Dynamics. Journal of Business $\mathcal{E}$ Economic Statistics, 12(3), 299-308.

Filardo, A. J., \& Gordon, S. F. (1998). Business Cycle Durations. Journal of Econometrics, 85, 99-123. https://doi.org/10.1016/S0304-4076(97)00096-1

Funke, M., Leiva-Leon, D., \& Tsang, A. (2019). Mapping China's time-varying house price landscape. Regional Science Urban Economics, 78, 103464. https://doi.org/10.1016/j.regsciurbeco.2019.103464

Ghent, A. C., \& Owyang, M. T. (2010). Is housing the business cycle? Evidence from U.S. cities. Journal of Urban Economics, 67, 336-351. https://doi.org/10.1016/i.jue.2009.11.001 
Goodwin, T.H. (1993). Business-Cycle Analysis with a Markov-Switching Model. Journal of Business $\mathcal{E}$ Economic Statistics, 11(3), 331-339.

Hamilton, J. D. (1989). A New Approach to the Economic Analysis of Nonstationary Time Series and the Business Cycle. Econometrica, 57(2), 357-384. https://doi.org/10.2307/1912559

Hamilton, J. D. (1994). Time Series Analysis. Princeton University Press.

Himmelberg, C., Mayer, C., \& Sinai, T. (2005). Assessing High House Prices: Bubbles, Fundamentals, and Misperceptions. The Journal of Economic Perspectives, 19(4), 67-92. https://doi.org/10.1257/089533005775196769

Howitt, P. (2001). Learning, leverage and stability, Brown University mimeo.

Huang, M. (2019). Markov-switching impacts of housing-market expectations on credit markets. Managerial Finance, 46(3), 381-400. https:// doi.org/10.1108/MF-08-2019-0391

Jarociński, M., \& Smets, F. R. (2008). House Prices and the Stance of Monetary Policy. Federal Reserve Bank of St. Louis Review, 90(4), 339-365. https:// doi.org/10.20955/r.90.339-366

Jin, Y., \& Zeng, Z. (2004). Residential investment and house prices in a multisector monetary business cycle model. Journal of Housing Economics, 13, 268-286. https:// doi.org/10.1016/i.jhe.2004.08.001

Kim, M. S., \& Coulson, N. E. (1999). Sources of Fluctuations in the Housing Market. International Economic Journal, 13, 57-70. https://doi.org/10.1080/10168739900080005

Kim, J. R., \& Chung, K. (2016). The role of house price in the US business cycle. Empirical Economics, 51(1), 71-92. https://doi.org/10.1007/s00181-015-1001-4

Martínez-Pagés, J., \& Maza, L. A. (2003). Analysis of house prices in Spain. Working Paper, no. 0307, Bank of Spain.

McCarthy, J. \& Peach, R. W. (2004). Are Home Prices the Next 'Bubble'? FRBNY Economic Policy Review, December.

McDonald, J. F., \& Stokes, H. H. (2013). Monetary Policy and the Housing Bubble. The Journal of Real Estate Finance and Economics, 46, 437-451. https://doi.org/10.1007/s11146-011-9329-9

Moolman, E. (2004). A Markov switching regime model of the South African business cycle. Economic Modelling, 21(4), 631-646. https:// doi.org/10.1016/j.econmod.2003.09.003

Nell, E. (1998). Transformational Growth and the Business Cycle. Routledge.

S'a, F., Towbin, P. \& Wieladek, T. (2014). Capital flows, financial structure and housing booms. Journal of the European Economic Association, 12(2), 522-546.

Semmler, W., \& Bernard, L. (2012). Boom-Bust Cycles: Leveraging, Complex Securities, and Asset Prices. Journal of Economic Behavior \& Organization, 81, 442-465. https://doi.org/10.1016/j.jebo.2011.07.002

Stock, J. H., \& Watson, M. W. (1991). A Probability Model of the Coincident Economic Indicators, in Leading Economic Indicators: New Approaches and Forecasting Records, K. Lahiri and G.H. Moore, Cambridge: Cambridge University Press, 63-89.

Stock, J. H., \& Watson, M. W. (1993). A Procedure for Predicting Recessions with Leading Indicators: Econometric Issues and Recent Experience. In Business Cycles, Indicators and Forecasting, J. H. Stock and M.W. Watson (pp. 255-284). University of Chicago Press for NBER. https://doi.org/10.7208/chicago/9780226774749.001.0001

Sun, C. (2012). Essays on the U.S. Housing Market and the Credit Market, Ph.D. Thesis. University of California, Riverside.

Tsai, I. C. (2019). Relationships among regional housing markets: Evidence on adjustments of housing burden. Economic Modelling, 78, 309-318. https://doi.org/10.1016/j.econmod.2018.09.026

Wang, P., \& Zong, L. (2019). Contagion effects and risk transmission channels in the housing, stock, interest rate and currency markets: An Empirical Study in China and the US. The North American Journal of Economics and Finance, Available online 16 November 2019, 101113. https://doi.org/10.1016/j.najef.2019.101113 